\title{
Technical report for a Lemon packing plant in southeastern Mexico regarding productivity, for the generation of an improvement model
}

\section{Informe técnico para una empacadora de Limon en el sureste de México en materia de productividad, para la generación de un modelo de mejoramiento}

\author{
LÓPEZ-ANZUREZ, Omar Alejandro†*, ELISEO-DANTÉS, Hortensia, LÓPEZ-VALDIVIESO, \\ Leticia and PÉREZ-GÓMEZ, Gerardo Ernesto
}

CONACYT / TecNM campus Villahermosa, Mexico.

ID $1^{\text {st }}$ Author: Omar Alejandro, López-Anzurez / ORC ID: 0000-0002-2769-4087, CVU CONACYT ID: 1003678

ID $1^{\text {st }}$ Co-author: Hortensia, Eliseo-Dantés / ORC ID: 0000-0003-4006-4669, Researcher ID ThomsonF-6749-2018, PubMed Autor ID: 6eb3adfd69824484b018f668c2670f109f08, CVU CONACYT ID: 411079

ID $2^{\text {nd }}$ Co-author: Leticia, López-Valdivieso / ORC ID: 0000-0001-6288-3636, Researcher ID Thomson: G-5753-2018 PubMed Autor ID: 88b3c7591c5b9c66b8657c78d9f44d708, CVU CONACYT ID: 67839

ID $3^{\text {rd }}$ Co-author: Gerardo Ernesto, Pérez-Gómez / ORC ID: 0000-0002-3681-3594, CVU CONACYT ID: 959329

\begin{abstract}
Productivity is the result that all organizations seek, but every day it is more difficult to achieve it and especially in the current context such as the pandemic generated by the Covid-19 virus, this need for transformation has provided new areas of opportunity throughout the world. world, generating new techniques, jobs and knowledge. This is the case of the present investigation that focuses on the realization of a technical report in the citrus exporting companies of the southeast of the area, taking as a reference the company GM citrus This report is carried out through a systemic approach and comprehensive, considering the use of the Comprehensive Technical Productivity Assessment tool (TIEP) that integrates within its application the evaluation of 10 priority elements to achieve productivity and therefore the quality of organizations. It should be noted that the information that integrates the tool and the elements is taken directly from the experts linked in the context of the study. It is of great importance to mention the participation of the personnel who collaborated to compile the information, as well as the experts who advised to be able to integrate a comprehensive scheme of the organizational scenario.
\end{abstract}

\begin{abstract}
Resumen
La productividad es el resultado que todas las organizaciones buscan, pero cada día es más difícil conseguirla y sobre todo en el contexto actual como la pandemia generada por el virus de la Covid-19 esta necesidad de transformación ha brindado nuevas áreas de oportunidad en todo el mundo, generando nuevas técnicas, empleos y conocimientos. Este es el caso de la presente investigación que se centra en la realización de un informe técnico en las empresas exportadoras de cítricos de la zona sureste del, tomando como referencia la empresa GM cítricos Este informe se lleva a cabo a través de un enfoque sistémico e integral, considerando el uso de la herramienta Técnica Integral de Evaluación de la Productividad (TIEP) que integra dentro de su aplicación la evaluación de 10 elementos prioritarios para lograr la productividad y por ende la calidad de las organizaciones. Cabe señalar que la información que integra la herramienta y los elementos, es tomada directamente de los expertos vinculados en el contexto del estudio. Es de gran importancia mencionar la participación del personal que colaboró para la recopilación de la información, así como los expertos que asesoraron para poder integrar un esquema integral del escenario organizacional.
\end{abstract}

Productividad, “GM cítricos”, COVID-19, Transformación

\begin{tabular}{llll}
$\begin{array}{l}\text { Productivity, } \\
\text { Transformation }\end{array}$ & "Citrus GM", COVID-19, & $\begin{array}{l}\text { Productividad, “GM cítricos”, COVID-19, } \\
\text { Transformación }\end{array}$ \\
\hline
\end{tabular}

Citation: LÓPEZ-ANZUREZ, Omar Alejandro, ELISEO-DANTÉS, Hortensia, LÓPEZ-VALDIVIESO, Leticia and PÉREZ-GÓMEZ, Gerardo Ernesto. Technical report for a Lemon packing plant in southeastern Mexico regarding productivity, for the generation of an improvement model. ECORFAN Journal-Republic of Peru. 2021. 7-13:12-16.

\footnotetext{
* Correspondence to Author (Email: lop.anzurez@gmail.com)

$\dagger$ Researcher contributing first author.
} 


\section{Introduction}

The export of citrus from Tabasco is now one of the most relevant economic activities for the state agricultural sector, of which the export of lemon stands out, which has increased considerably in recent years. Tabasco is among the ten leading states in citrus production and export, with the United States of America being the main recipient of the product.

The measurement of the processes allows to identify the main problems in a specific way, in such a way that it provides better understanding when locating the areas of opportunity and improvement, that is why productivity is a key pillar in any organization with the which determines a comprehensive approach that benefits all stakeholders, analyzing each of the context variables.

The lemon packaging process is a key piece to improve the development and productive capacities of the Chontalpa area of the state of Tabasco, as well as this process presupposes social development and cultural development in this region by providing employment in remote areas of the municipality of Huimanguillo, which has been a key piece for the current agro-industrial development in the lemon production sector in the state of Tabasco.

The development of companies in this region is of vital importance for economic and social well-being, to take advantage of the unique characteristics of the soil for lemon production and labor, and no less important is the consolidation of existing companies that generate jobs. and new business opportunities for the full utilization of the fruit.

The development of this project is determined by the need to evaluate the productivity in the Persian lemon packing company "GM" citrus, in order to maintain a good productive level and know the current situation of the organization, through the application of the tool "Comprehensive Productivity Assessment Technique" with the purpose of analyzing the ten elements that every organization must take into account to improve the system.

\section{Method description}

To give continuity to this improvement in productivity, a tool called: Comprehensive Evaluation Technique for Productivity (TIEP) was applied, which identifies how the context variables influence the ten elements that every organization should have. To integrate the knowledge and development of the organization, these elements are essential for the comprehensive knowledge of the company and integrate a series of general and specific aspects that denote the productive scope of the company.

Elements:

1. Conceptual approach of the company.

2. Knowledge of the processes.

3. Social scope of the organization.

4. Planning administration.

5. Management participation.

6. Creativity and organizational innovation.

7. Knowledge of customers.

8. Technological development.

9. Macroeconomic knowledge.

10. Comprehensive development of human resources.

The Comprehensive Technical Evaluation for Productivity instrument (TIEP) is a tool that gives us the security of being able to evaluate ten fundamental elements that every organization must have, with this generate a concrete measurement through a qualitative and quantitative analysis that relates the elements to the context variables; Environmental, Cultural, Economic, Social, Political, Technological, that could influence the productivity of the organization. 
It is considered that the evaluation is carried out in each of the departments that make up an organization and can be segmented by a group of departments, this is carried out personally so that the interviewer can start a conversation that integrates questions with which he qualifies his criterion in which way the variables influence each of the elements and their relationship.

\section{Analysis from the method}

The study of productivity through the TIEP tool allowed the organization to obtain results with a view to applying a comprehensive approach, analyzing the different elements that every organization must integrate into its work areas and identifying the impact of context variables on these, to determine the productive level of the company.

This study will focus on all the processes of the company "GM" citricos, where the following areas were taken as a reference for their study:

\section{Management.}

Financial.

\section{Shopping.}

Operations.

\section{Assortment.}

The application of 5 instruments will be considered, one in each of the aforementioned areas to analyze the 10 elements that every organization must integrate into its organization to control and improve productivity.

\section{Results}

Perfil de productividad de la organización por promedios simples

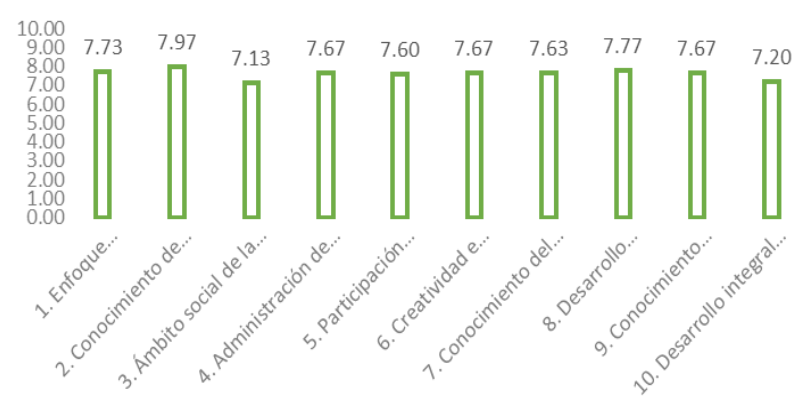

Graphic 1 Organization productivity profile Source: Author's elaboration, 2021

ISSN-On line: 2414-4819

ECORFAN $^{\circledR}$ All rights reserved.
In the integral graph of the productivity profile of the organization the relationship of each of the areas is observed and it is summarized in the following, the areas are at a balanced level downwards given the interpretation of the graph, however there is the impact of the variables on each of the elements, this greatly influences the results and, as can be seen in the graph, the weight of the variables in the elements is notable, above all there are more notable points for the variables; economic, environmental, political and social.

The items with the lowest score; Social scope of the organization, integral development of human resources represent the incidence of the variables, as well as a performance with areas of opportunity, which by means of the design of an improvement model, those points that would specify and help to raise the score can be identified of the organization.

\section{Perfil de productividad de la organización por promedios Compuestos}
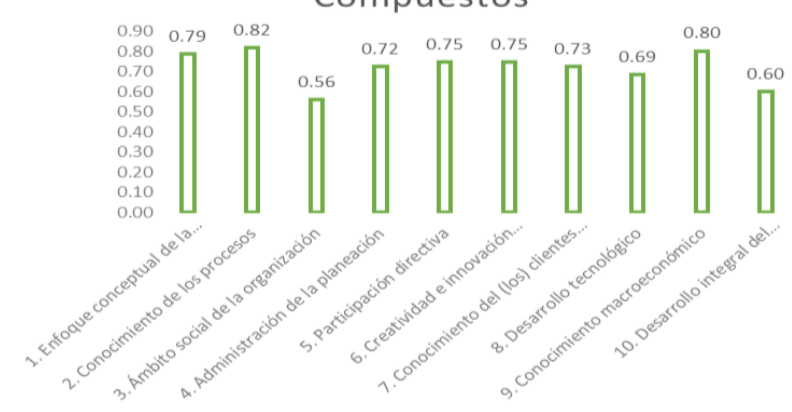

Graphic 2 Organization productivity profile Source: Author's elaboration, 2021

In the following Graphic we can see more clearly, where this score leans, which is one of the red flags for the institution. The social scope of the organization is of great importance for all organizations since that is where what we know as the work environment comes from, during the measurement a system was not found in which the social scope was measured and it was not considered important. In the organization.

In the same way, a higher score is presented on the element "Comprehensive development of human resources", this despite having a low score, is directly related to the previous one, since the company does not have measurement indicators to know how the human resource development, the Tampóco company has a human resource retention system, there is no monthly or annual indicator of the people who are no longer working in the organization.

LÓPEZ-ANZUREZ, Omar Alejandro, ELISEO-DANTÉS, Hortensia, LÓPEZ-VALDIVIESO, Leticia and PÉREZ-GÓMEZ, Gerardo Ernesto. Technical report for a Lemon packing plant in southeastern Mexico regarding productivity, for the generation of an improvement model. ECORFAN Journal-Republic of Peru. 2021 
The development of human resources is observed as one of the most relevant points in the study, but the one with the least focus on the part of the organization.

\section{Proposal}

The GM citrus company is an organization committed to the processing industry, lemon export, and regional development, it is a company that is in the process of development and consolidation, currently occupies a place within the ten lemon exporting companies of the region. Which leads us to mention that in the measurement of its areas it was possible to determine that it is at a stable level with a negative perspective, given the scores obtained in the, it was found incidence of the variables in the elements evaluated in each area, determining that the impact of these influences to a great extent the performance and achievement of the objectives.

Various areas of opportunity were found detected by the measurement of the elements and their interaction and incidence of the context variables, the organization whose main objective is economic stability like that of any other organization, has neglected the importance of planning Therefore, retaking and establishing the review of the strategic plan of the company is one of the main proposals for the organization, and include a system of indicators in which all the processes that are carried out on the site can be integrated, and with this, having the ability to improve the growth of the company.

It is recommended to integrate all the processes to a quality management system, with this having the certainty that everything meets the necessary standards for each of the processes, and the door is opened to meet the requirements of any audit system and having a passing audit can help develop new business with other clients.

Another area of opportunity detected is the high staff turnover that the company has, although this was documented in the interviews, there is no turnover indicator, therefore, it is not measured and cannot be improved, staff turnover is an element that is influenced by various factors, for which the creation of a human resource development program is proposed.

\section{Productivity improvement model}

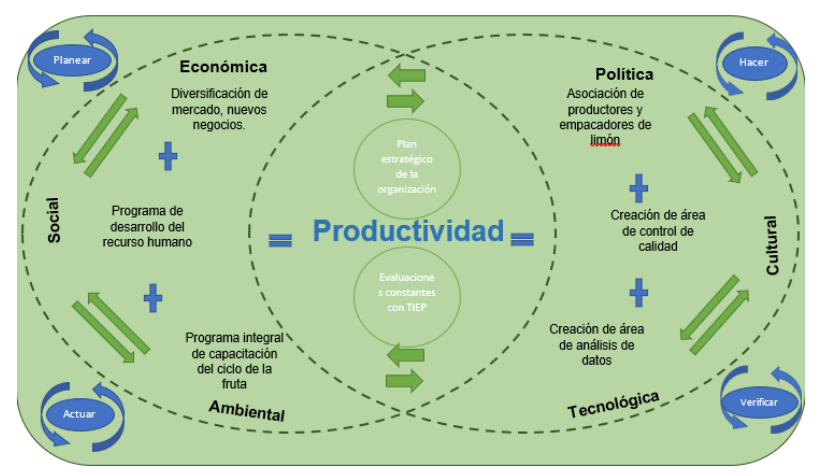

Figure 1 Productivity improvement model Source: Author's elaboration, 2021

In the model presented, all the interaction that exists in the system that is the company is visualized, like a Venn diagram, where what is sought by the two circles is productivity. On the external side are the cycles of continuous improvement where we begin with planning, doing, verifying and acting, the continuous cycles of continuous improvement affect the entire model for the organization, it is relevant to understand that all the actions that are carried out carried out in the organization must be marked by root cause analysis and true corrective actions.

Below we present some initiatives that are stipulated in the model to achieve productivity improvement:

Diversification of new markets: $70 \%$ of its sales are for export, the rest remains in the national market, but due to the pandemic, its main client lost a chain of retail sales in the United States of North America, its sales They had a decrease of $20 \%$, therefore diversifying other businesses, such as sales to commercial chains in Mexico and special businesses such as supply centers, bars and tea companies. Human resource development program: This program seeks to have information first of all about the rotation that exists in the company, and develop the capacities and abilities of the staff, first it is recommended to have a job description, and create a matrix of skills, to always know the human resource that the company has, do a battery of courses starting with an institutional one and then, depending on their position, those that are required to fulfill their obligations. 
Comprehensive training program of the fruit cycle: This program is ambitious, since it seeks to intervene in the culture of certain suppliers, to facilitate the knowledge of the cycle of the characteristics of the fruit and with this have a strength with your suppliers and with your own workers.

Association of lemon producers and packers: Since Huimanguillo is the municipality with the highest lemon production in the state, it is necessary to seek to have a regulator and policy facilitator for the benefit of the region, in this there is not a strong impact on the part the company, but it can be the one that manages some of the actions with the current government.

Creation of quality control area: It is recommended to create this area for the creation of the necessary documentation and the inspection process upon receipt of the products upon arrival to have greater certainty in the quality of the products.

Creation of data analysis area: In every current company there must be a data management area, due to the amount of information that is generated in all companies and particularly in a company where external variables add an important force in the taking of daily decisions.

\section{Acknowledgments}

This research is the result of the effort and cooperation between the organization and all those involved in its development, who gave full support and consideration to the author.

We are grateful to the colleagues who were involved in the development of this research, as well as the advice provided to obtain feedback on the work.

\section{Conclusions}

As a conclusion to this research, it is determined that the GM citrus company is at a stable negative level, however, it is shown that the context variables and their impact on the elements can influence the results obtained at a given time.
It is suggested that the organization start as soon as possible with changes or improvements to the system, since this will greatly benefit the staff as well as the organizational performance, providing a better service based on quality and productivity.

The review and scheduling of the strategic plan of the company is recommended for its review and update in the points that are necessary, it is of relevant importance that the company can create a manual or electronic system of indicators, to have a visibility in time and form of what for the company generates value and waste within the process, those activities that are within the immediate and in which you do not have to have such an unexpected monetary investment for the budget, it requires time and teamwork for the assignment of activities for the revision of these points.

The materialization of the model can be specified in its application, taking as a starting point the research given here, as these are internal aspects of the organization and to a large extent none affect the processes of this, you can continue with the activities In its normality, however, the review of the strategic plan is of high importance, to carry out the recommendations mentioned, as well as carry out periodic evaluations using the TIEP tool, since it ensures concrete and stable results that seek the full benefit of the organizations.

\section{References}

Eliseo H. (2016) Apuntes de Creatividad e Innovación en las organizaciones. México. p.p. $18-64$.

Eliseo H. (2021) Técnica integral de evaluación de la productividad. Villahermosa, Tabasco, México. 